\title{
The Era of Xi Jinping (2012-2016)
}

Thus, by the time Xi Jinping took over as the new leader of China he was faced with a situation of classic financial repression, namely highly regulated low interest rates, an undervalued exchange rate (encouraging investment in export industries), and continued capital controls. This had benefited the traditional state-owned sector of the economy and had led to a situation of oversupply of energy-intensive and polluting heavy industry and other problems of imbalanced economic development. In the social field, the social fabric and political stability was threatened by huge income disparities. There was a widespread feeling that the broad masses of Chinese consumers had not received their fair share of economic growth. They had experienced higher incomes and a substantial increase in their standard of living, but the share of consumption in GDP had decreased to 36 percent, indicating that investment still took priority.

In particular, President Xi Jinping and Prime Minister inherited an economy characterized by excessive investment and low consumption and showing clear signs of overcapacity. China produced more than half of the world's output of steel, aluminum, cement and coal, and had also seen explosive growth in sectors such as glass industry and paper industry (Haley and Haley 2013; EU-China Chamber of Commerce 2016). As a result of slowdown of economic growth, China was not able to absorb this production output. There was also increasing pressure from international trading partners who complained about Chinese exports at dumping prices.

The first major initiative of the new leadership was to launch a comprehensive anti-corruption reform which was aimed at "flies" as well as "tigers" and was targeted at government and Party officials as well as soes. The campaign was followed by anti-extravagance campaign aimed at reducing public spending on banquets, official cars and travelling. However, during most of 2013, Chinese economists and planners concentrated on formulating a new major reform program.

The new reform program was presented at the third plenum of the eighteenth Central Committee held in November 2013. It was a comprehensive reform program containing no less than 340 reform proposals. The program entitled "The Decision of the CPC Central Committee on Some Important Questions concerning Comprehensively Deepening Reform" was allegedly the result of more than half a year's drafting under the supervision of Xi Jinping (Xinhua 2013). 
The Decision of the third plenum changed the wording concerning the role markets play in the Chinese economic system from "basic" to "decisive." The notion of the "supplementary" role of the market in resource mobilization and allocation was written into the Constitution in 1982 (Brødsgaard and Grünberg 2014). Since then several Party congresses "upgraded" the role of the market in their programs. In 1988 the Constitution was amended to include the private sector as a "complement" to the socialist economy and in 1993 the concept of the "socialist market economy" was introduced. In November 1993 the third plenum of the fourteenth Central Committee adopted a Decision which stipulated that the market was to play a "basic" role (Renmin Ribao 1993). The Decision of the third plenum in November 2013 went a step further by underlining that market-based price mechanisms were to be applied in all instances where "the market can determine the price," including natural resources and energy (article 10). Better integration of internal markets in order to address market distortions across regions in China was planned. Also, more unified foreign capital entry regulations, a general opening up toward outside financial markets and even the systematic preference of finance were mentioned (article 12). In terms of rhetoric the Decision goes further than at any time in PRC history in terms of official focus on market regulation and market prices. Not even the 1956 debate on the role of market went this far.

The Decision also signaled important reform in the state sector of the economy. The most far-reaching proposal was to establish a mixed ownership system, including allowing investments in publicly owned entities by private capital (article 6). The aim was to abolish the monopoly status of soes and introduce competition in sectors formerly monopolized by them. The Decision also introduced a classification of "monopoly enterprises" and "competitive enterprises." soes in natural resources and public utilities would be considered natural monopolies. However, in the future they would be exposed to market-based pricing of oil, electricity and water and no longer enjoy subsidized access to these resources. They would also have to separate government administration and business operation, while also reforming selection, evaluation and remuneration of management (article 7). "Competitive enterprises" would be exposed to competition and marketized resource allocation and would be allowed to hire executives with salaries based on market criteria. The overall aim was to shift the focus from asset management to capital management. This was a policy proposal put forward earlier by Chen Qingtai, who worked closely with Zhu Rongji and who is still regarded as an influential advisor to the State Development Research Center (Chen 2012). Some Chinese economists also mentioned Singapore's Temasek Holding as a future model for how the State Assets Supervisory and Administration Committee (SASAC) could manage 
the large Chinese central enterprises that form the core of the Chinese soes (SASAC 2012).

The Decision underlined the importance of establishing a mixed ownership system which would allow private capital to invest in publicly owned enterprises. Allowing private investment into SOE would mean a substantial upgrading of the role of private capital in the Chinese economic system. These investments could take the form of minority private shareholding in SOEs or the establishment of cooperative state-private ventures. Although this reform entailed significant changes in the role of private capital, a privatization program involving private control over major soes was not on the agenda.

Reforms of banking and financial regulation also figured prominently in the reform document. Competition in the financial sector was to be stimulated and small and medium-sized private banks would be allowed to open, providing private enterprises with better access to loans. Of particular importance was a stipulation that interest rates were to be liberalized. According to Central Bank Governor Zhou Xiaochuan this reform would be implemented within a two-year period. If fully implemented such a reform would involve a basic change of the mechanism of financial repression.

The Decision seemed to indicate a commitment to finally implement soE reform. This impression was reinforced by public statements and interventions by Chinese officials and scholars in late 2013 and early 2014. However, from late 2014 the debate shifted in the direction of consolidation of soes rather than breaking them up into competing units. The stated intention was to merge companies in order to create even bigger monopolies within sectors such as telecom, oil and gas, shipbuilding, power generation and so on. In official statements such mergers are necessary in order for Chinese "national champions" to be able to compete at the global-level playing field where the competition is vicious (elie). During 2015 and 2016 mergers included cosco and China Shipping, China Nuclear Power Investment Group and Nuclear Power Technology Group, Wuhan Steel and Baosteel. Mergers and acquisitions on this scale will work against the spirit of the Decision to create competition and possibly break up SOE monopolies into smaller units.

However, it is noteworthy that the Decision did not mention the conflict between lower economic growth rate and excess capacity that Wen Jiabao had discussed in his report on the work of the government in spring 2013. Dealing with this problem involved the soes, as it was primarily companies within the state sector that were engaged in excess production and were unwilling to reduce output.

In 2014-2015 the Chinese economic growth rate entered a downward spiral and at the end of 2015 the growth rate had slowed down to 6.7 percent, 
the lowest since 1990 (see Table 11). However, even though domestic demand had fallen and export was declining due to weakened international demand, soes were reluctant to cut down on production. The government had to step in and implement a policy of reduction of overcapacity and excess production. The policy was first mentioned at the fifth plenum of the eighteenth CCP Central Committee in late October 2015 under the name of supply-side structural reform (gongji ce tizhi gaige). Shortly after the plenary session, Xi Jinping, at a meeting of the Central Leading Small Group for Finance and Economics, delivered a speech stressing the importance of supply-side structural reform (Naughton 2016b). Yang Weimin, the vice-director of the Leading Small Group, underlined that stimulating demand was no longer the focal point of economic reform and policy, and at the annual Central Economic Work conference held in December 2015, supply-side reform was defined as a framework and guide for China's future growth.

According to Yang Weimin, supply-side reforms include "four annihilation battles": (i) eliminate excess capacity; (ii) reduce costs (for companies); (iii) reduce excess housing stocks; and (iv) contain financial risks. ${ }^{250}$ Reforms in the battle against costs are mainly aiming at reducing costs for companies. This includes lowering taxes and easing financial burdens and labor costs. In particular, soes are supposed to undergo processes of cost reduction (Sina Finance 2015). Reducing housing stocks is primarily aimed at reducing stocks of unsold housing in second- and third-tier cities. Especially the inventory of real estate held by public organs and soes is targeted. Local governments and soEs have long used real estate as investment, but, with increasing oversupply, real estate has become a liability for many companies who were not supposed to engage in real estate speculation in the first place. ${ }^{251}$ Deleveraging or containing financial risks involves restructuring debts. Some companies are deeply in debt and local governments have also developed huge debt burdens.

Eliminating excess capacity is perhaps the most important part of supplyside reform. It takes center stage because as the Chinese economy has slowed, demand for heavy-industrial products has dropped, even though capacity has continued to grow. The result is massive overcapacity, especially in steel and coal. In the case of steel China now produces more than half the world's production. Hebei alone produces almost four times as much steel as the USA. The Chinese government has established a target of 100 to 150 million metric tons of capacity reduction within the next three years. Coal is next in line, with projected closures of mines in Inner Mongolia, Shanxi and Shaanxi. After steel

250 See "Yang Weixin xiangjie gongji ce gaige: da sige 'jianmie zhan'” (2015).

251 "Xi Jinping ti sige jianmie zhan loushi qu cun weilie qizhong" (2015). 
and coal, it is the intention to deal with overcapacity in cement, chemicals, electric power and non-ferrous metals.

\section{Massive Overcapacity}

A report from the European Union Chamber of Commerce in China released in spring 2016 outlined the extent of the problem in eight sectors: crude steel, electrolytic aluminum, cement, chemicals, refining, flat glass, shipbuilding, paper and paperboard (European Union Chamber of Commerce in China 2016). The report defines excess capacity as the difference between production capacity and actual production. The report noted that overcapacity is not a new phenomenon. In fact, even in 2009 the Chinese government admitted that overcapacity had become a serious problem and that local governments were continuing to expand capacity "blindly" (ibid., p. 5). The EU Chamber of Commerce in China at the time released a report that provided recommendations as to how the problem could be brought under control. These recommendations, as well as the report, were presented to the EU-China Summit that took place in Nanjing in November 2009 (ibid., p. 1). Yet despite an awareness of the problem no concentrated efforts to remedy the situation were made. In fact, while red signals were hoisted, the Chinese government rolled out a massive stimulus package that benefited these sectors, creating even greater overcapacity.

According to the EU-China Chamber of Commerce report, by 2014 the steel sector was producing yearly 813 million metric tons, more than half global output or more than twice the combined output of the next four biggest steel producers: Japan, India, the USA and Russia. ${ }^{252}$ Actually China's steel mills had a combined output capacity of $\mathbf{1 . 1 4}$ billion tons. Consequently, the utilization rate was only 71 percent, indicating massive excess capacity. In other words, China in 2014 had an overcapacity in the steel sector almost equal to the combined output of Japan, India, the UsA and Russia.

China's electrolytic aluminum industry also has shown rapid growth in recent years. The country now accounts for half of global production. According to the report the industry has a capacity of 38.1 million tons, but only 28.9 tons were produced in 2015, resulting in a utilization rate of 76 percent. China is also a global leader in cement production, accounting for 57 percent of global output. In fact, in the three years between 2011 and 2013 China used more cement

252 In 2000 China only produced 129 million tons of steel (Kroeber 2016, p. 50). 


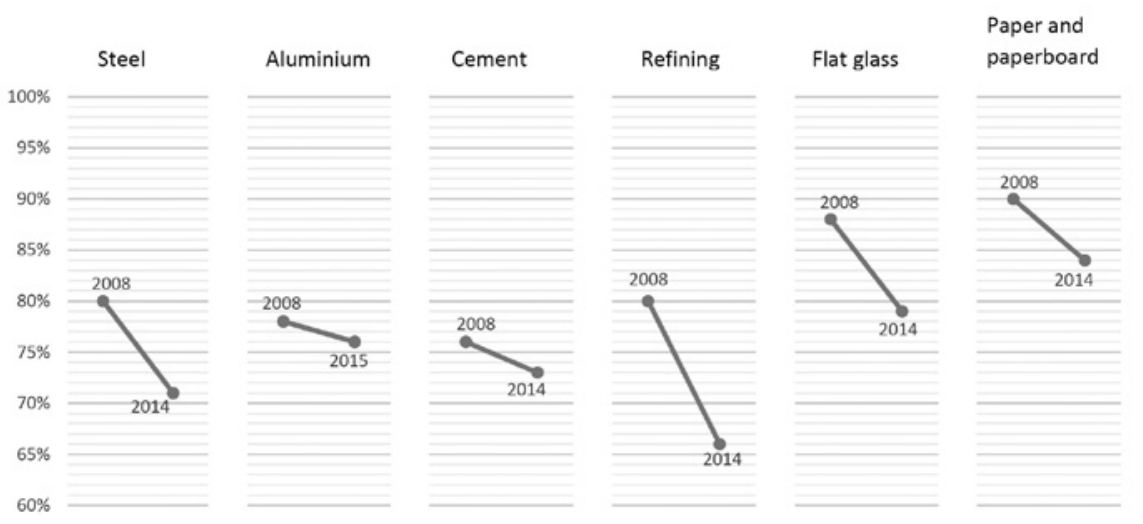

FIGURE 13 Utilization rates for six industries (\%).

SOURCE: EUROPEAN UNION CHAMBER OF COMMERCE (2016).

than the USA did in the entire 2oth century. ${ }^{253}$ The capacity of the Chinese cement industry is an enormous 3.1 billion tons. In 2014 the country "only" produced 2.25 billion tons, a utilization rate of 73 percent. Similar to steel and aluminum, the cement industry had shown significant excess capacity in 2008, yet the problem was not addressed and investment continued to be poured into these crisis-stricken sectors.

The report also discussed the reasons for the outlined overcapacity. It mentions that excess capacity was a problem long before 2008 but the global economic downturn following in the wake of the global financial crisis aggravated the issue. In the late 1990s Zhu Rongji tried to deal with a somewhat similar crisis by shutting down numerous soes and laying off almost 40 million workers in the state sector. This was his way of dealing with the severe overinvestment problems. The report argues that from 2002-when Zhu Rongji had stepped down-China's state-owned heavy-industrial economy experienced a new boom and within the space of five years the relative size of heavyindustrial production in the economy nearly tripled (ibid., p. 8). Before the global financial crisis China was able to export a significant part of the goods that the domestic economy was not able to absorb. With the recent downturn in exports as result of less demand from global markets, especially the EU and the USA, China can no longer use exports as a "safety valve." Moreover, the low export price of steel and other products are hurting the domestic industry in these markets, creating demands for measures against what is perceived to be unfair competition by China.

253 These are estimations by Vaclav Smil cited in Kroeber (2016, p. 277). See also Swanson (2015). 


\section{Zombie Enterprises}

A central plank of China's supply-side reform is the reform of China's $c .150,000$ soEs, and in particular getting rid of the so-called zombie companies. These are companies that have suffered losses for a long time. They consume a large amount of resources, such as land, funds, energy and labor, reducing the efficiency of resource allocation and preventing resources being directed to sectors of higher economic efficiency. Although they have no way to continue their operations, they have not declared bankruptcy. They have been able to use bank loans or government funding to survive. Often local governments are reluctant to see them close down and make great efforts to bail them out as closure will create unemployment in the local area as well as reduce the local tax base.

Longmay Group, for example, is the largest coal company in northeast China. The Group reported large net losses in 2012 and 2013. In 2014 losses increased to 6 billion yuan (Wang 2016). The production capacity of Longmay is only one tenth of Shenhua Group, the leading company in the coal sector, but both companies employ about 200,000 workers. In October 2015 it was reported that Longmay planned to lay off 100,000 workers (Hornby 2016). However, according to company statements many of the workers would be diverted to affiliated companies, a sign of political pressure to maintain jobs and avoid unemployment in a region which is struggling to keep up with the more dynamic regions in southern China. Laying off workers may cause protests by those affected. This in fact did happen in the case of Longmay.

The governor of Heilongjiang, Lu Hao, claimed during the meeting of the National People's Congress in Beijing in March 2016 that no miner working for Longmay was owed any back wages. Lu Hao's statement was met with strong protest from thousands of miners who, the following day, marched through the city of Shuangyashan and gathered in front of the company's local offices demanding to be paid. In response the provincial government issued a statement acknowledging that the governor had been misinformed and that Longmay in fact had failed to pay wages and insurance contributions. The statement also said that the government would cooperate with Longmay to raise money to pay the workers in time (Taipei Times 2016).

In January 2016 a report from China International Capital Corp. claimed that 3 million jobs of the 10 million currently available in the coal, steel, aluminum, cement and glass industries would be cut over a three-year period (EU-China Chamber of Commerce 2016, p. 44). This is the first time since Zhu Rongji restricted the state sector in the late 1990s that the Chinese government is laying off workers in large numbers. The government is clearly aware of the problems 
this may create and is busy softening the economic repercussions for the workers affected. In his report on the work of the government delivered to the fourth session of the twelfth NPC on March 5, 2016, Premier Li Keqiang mentioned that 100 billion yuan in rewards and subsidies would be provided by the central government ( $\mathrm{Li}$ 2016). These funds would mainly be used to resettle employees laid off from soes. In May 2016, the Ministry of Finance said in a statement that 80 percent of the funds would be distributed to local governments and central enterprises based on their capacity, reductions assignments and the number of workers that would be laid off. The rest of the funds would be used as a form of bonus, to be allocated based on how well local governments and soEs fulfilled their assignments (Beijing Review 2016).

Supply-side reform is a top-down initiative emerging from the central government in Beijing. However, the implementation of the program is to be undertaken by provincial governments in provinces where most industrial companies engaged in excess production are physically located (Naughton 2016a). Consequently, each province must draft plans for cutting down on heavy-industrial capacity. Hebei, which produces almost one quarter of China's steel output, has agreed to reduce its steel production by 49 million tons by 2020 and 14 million tons by 2016. ${ }^{254}$ Other steel-producing provinces, such as Shandong and Jiangsu, have agreed to reduce output by 16-23 percent within the 13th Five Year Plan period (2016-2020). As provincial leaders are eager to be part of the comprehensive round of promotions that will take place in connection with the 19th Party congress, they are strongly motivated to follow central policies. ${ }^{255}$ However, in doing so they are confronted with powerful vested interests that feel hurt by production cuts.

Supply-side reform will mainly affect the soes. There are 150,000 of these and they are found at both central and local levels. The most important are the 106 so-called central enterprises that dominate the strategic sectors of the economy and in fact enjoy a monopoly status. Industries such as steel, cement and glass are highly fragmented, with multiple comparatively inefficient small local enterprises. Many of these will now be closed down and local governments will have to work out plans for how this is to be done. At the central level the government will pursue a different policy. As mentioned above, the current strategy is to merge many of the large SASAC companies in order to

254 "Quanguo gedi gangtie qu channeng zhengce chulaile!" (2016).

255 Five provincial leaders are members of the Politburo and are possible candidates to enter the Standing Committee of the Politburo at the nineteenth Party congress in 2017. These are Guo Jinlong in Beijing, Han Zheng in Shanghai, Hu Chunhua in Guangdong, Sun Zhengcai in Chongqing and Zhang Chunxian in Xinjiang. 
create even bigger monopolies. The intention is to strengthen the international competitiveness of China's "national champions." Moreover, central soes will be allowed to make acquisitions among companies on the list of those to be closed or phased out. Such mergers and acquisitions will work against earlier plans to break up SOE monopolies into smaller units.

For decades soes in China have enjoyed preferential treatment. The Decision of the third plenum seemed to indicate that the private sector in the future would enjoy better treatment. In his 2016 government work report, Li Keqiang argued that the government would energize private companies by allowing them to compete with soEs. This makes economic sense as private companies in China in general are more profitable than soEs. However, politically the state sector is still considered the heart of the economy. Thus, private capital will not be allowed to play a significant role in any of the strategic sectors currently dominated by the 106 central enterprises or "national champions." The Party realizes that, left on their own, the soes are not yet able to weather the fierce competition on the global-level playing field. Almost half of the central enterprises are on the Fortune 500 list, where China now has 103 companies. Three of them are among the top ten companies in the world according to the list. ${ }^{256}$ In terms of revenues and size of the workforce they are big. However, they are weak in terms of R\&D and branding (Nolan 2012). This is a major impediment to their ability to succeed and therefore they need to be supported by the state via cheap bank loans, and preferential access to land and low-priced energy sources. The funds for all this come from the Chinese consumers and are made available by the mechanism of financial repression.

\section{3th Five Year Plan and New Normal}

Supply-side reform in China is part of part of Xi Jinping's framework for the so-called New Normal. This is a policy which projects an economic slowdown, from double digit growth during the 1990s and 2000s to an annual growth rate of around 6.5 percent during the period of 2016-2020. According to the 13th Five Year Plan, adopted at the NPC in March 2016, and the First Five Year Plan, worked out under the direction of the $\mathrm{Xi}-\mathrm{Li}$ leadership, the slowdown involves a restructuring of the economy toward a more balanced, green,

256 In 2001 China only had ten companies on the Global Fortune 50o List. China now has twice as many on the list as Japan ( 52 companies) and is rapidly catching up with the USA (134 companies). State Grid, CNPC and Sinopec are numbers two, three and four on the list, only surpassed by Walmart. The list is available at: <http://beta.fortune.com/ global500/list>. 
consumption-driven, innovative and service-oriented development path (Xinhua 2016). This involves focus on green and innovation-driven development, upgrading of the industrial structure and output, increasing the contribution of consumption to economic growth and reducing the role of investment, raising people's living standard and quality of life, eliminating remnants of rural poverty, advancing environmental protection and modernizing the national governance system. In order to make sure that Party and state officials follow the line and do not engage in corrupt and wasteful practices, the Five Year Plan also stipulates that the current anti-corruption campaign will continue. Except for the part on anti-corruption, many of these elements were already part of the 12th Five Year Plan, worked out under the previous leadership team of Hu Jintao and Wen Jiabao and covering the 2011-2016 period ("Zhonghua Renmin Gongheguo" 2011).

One of the more prominent policy initiatives mentioned in the 13th Five Year Plan is the so-called "One Belt, One Road" initiative. The One Belt, One Road concept was first presented in September-October 2013 during Xi Jinping's visit to Kazakhstan and Indonesia (Swaine 2015) ${ }^{257}$ The idea is to connect China, Asia and Europe in terms of trade and economic interaction via a land route ("the belt") as well as a maritime route ("the road"). The Chinese government has established a development fund of $\$ 40$ billion to finance some of the initial projects connected with the initiative. The 13th Five Year Plan states that China intends to build an infrastructure network connecting every Asian subregion and linking Asia, Africa and Europe. In cooperation with countries taking part in the project, it involves establishing road, railroad, water and airway links, and building logistic corridors. The plan specifically mentions the construction of following economic corridors: the China-Mongolia-Russia Economic Corridor (CMREC), the New Eurasian Land Bridge (NELB); the China-Central and West Asia Economic Corridor (CWAEc); the China-IndoChina Peninsula Economic Corridor (CIPEC); the China-Pakistan Economic Corridor (CPEC), and the Bangladesh-China-India-Myanmar Economic Corridor (BCIMEC). As part of these, major infrastructure projects such as port infrastructure and industrial hubs will be constructed.

The countries potentially part of the One Belt, One Road initiative include 60 emerging market countries and developing countries with a total population of 4 billion, more than half the world's population, and an economic aggregate of $\$ 21$ trillion, almost a third of global GDP. Given its geographic scope and the number of countries and people involved, $\mathrm{Wu}$ Jianmin, former ambassador to

257 The Silk Road Economic Belt was unveiled at Nazarbayev University, Kazakhstan, in September 2013. The New Maritime Silk Road was announced before the Indonesian Parliament on October 3, 2013. 
France and former president of China Foreign Affairs University, has described the One Belt, One Road project as "the most significant and far-reaching initiative that China has ever put forward" (Wu 2015). One might add that if all these plans materialize, huge construction works will be needed, requiring steel, cement, aluminum and other products in sectors that are plagued by overcapacity in the domestic Chinese market. Thus, a successful One Belt, One Road initiative will help China minimizing its problem of excess capacity.

\section{Conclusion}

Chinese economic development has come full circle. In spite of official rhetoric fixed capital investment has consistently been kept at high levels and reached 44.6 percent of GDP by 2010 . Only in the early 1960 s was it possible to reverse the trend, but the outbreak of the Cultural Revolution made it impossible to sustain a readjustment policy based on a comparatively low investment rate, a reordering of sectoral balances and agricultural reform. When investment, in the 199os and especially the 200os, significantly began to rise again, the accumulation mechanism shifted from the traditional price-scissor of transferring resources from agriculture to industry to a mechanism based on financial repression. As a result, farmers and the agricultural sector are no longer alone in transferring resources to the industrial sector. In fact, the broad masses of consumers, through their savings, are making continued state support of heavy industry possible.

The accumulation model also has a political dimension. The state sector is of crucial importance to the ruling party. State ownership and soes are supposed to reflect a higher stage of socialist development than other forms of economic ownership and economic organization. The state sector is also an important recruitment base for future Party and state leaders. The so-called "national champions" are all state-owned companies and they totally dominate the strategic sectors of the economy. The communist regime will not be able to survive an abolishment of the soes and a full-scale privatization of the economy. Party leaders are keenly aware of this, yet there is an urgent need to change a development strategy that has run out of steam. Consequently, selected reforms, such as supply-side reform, and a change of the mechanism of financial repression are needed. At the same time, it is realized that implementation is crucial to sustained change. For decades Chinese economic development has relied on resource mobilization. Now it is time to change to resource efficiency. 